\title{
PROGRAM DIVERSIFIKASI PRODUK OLAHAN IKAN PATIN BERBASIS ZERO WASTE DI KELURAHAN PAHANDUT SEBERANG
}

\author{
Maryani $^{1}$, Ida Ratnasari ${ }^{2}$, Nursiah ${ }^{3}$ \\ 1,2,3 Universitas Palangka Raya \\ maryani@fish.upr.ac.id
}

\begin{abstract}
Pahandut Seberang urban village is one of the centers of catfish fishery cultivation in Palangka Raya City. The main focus of fish farmers in the Pahandut Seberang area as a partner area is the development of fish farming only. Farmers' attention to the diversification of processed fish products to increase the added value of this commodity has never been thought of before. The facilitation of technology package (Ipteks) community diversification of processed fish products that applies the principle of zero waste that utilizes all parts of catfish, namely meat, skin, tail, bones and head needs to be done. The purpose of this PKM is to increase partners' knowledge and skills on diversification of processed catfish products by applying the concept of zero waste. The method used in achieving these goals is the active participatory empowerment of the community through collaboration with partners, namely the transfer of knowledge and technology through training activities for diversification of processed catfish products by applying the concept of zero waste. The results achieved from this PKM activity that is an increase in knowledge and skills of partners in an effort to increase the diversification of processed local fishery products so as to increase the added value of catfish, can also apply the concept of zero waste in the processing of catfish, so that income more optimal society. Keywords: diversification, catfish, zero waste, Pahandut Seberang.
\end{abstract}

\section{PENDAHULUAN}

Kelurahan Pahandut Seberang merupakan salah satu kelurahan dan wilayah administratif Pemerintah Kota Palangka Raya. Kelurahan ini terletak di seberang Sungai Kahayan tepatnya bagian dari wilayah Kecamatan Pahandut namun wilayahnya terbelah oleh sungai Kahayan. Wilayah ini memiliki potensi perikanan yang sangat besar, sehingga masyarakat di Kelurahan Pahandut Seberang ini lebih banyak bermata pencaharian sebagai pembudidaya ikan. Perhatian para pembudidaya ikan pada diversifikasi produk olahan ikan untuk meningkatkan nilai tambah komoditas ini belum pernah terpikirkan sebelumnya. Padahal jika bahan mentah (ikan) tersebut diolah dengan sedikit proses saja, maka akan mampu meningkatkan nilai jual ikan tersebut. Belum adanya pasar produk olahan dari ikan patin di wilayah ini akan membuka peluang besar bagi kelompok petani ikan patin untuk sukses dibidang usaha ini terlebih jika diversifikasi produk olahan ini menerapkan konsep zero waste.

Ikan dan hasil perikanan lainnya merupakan bahan pangan yang mudah rusak, antara lain karena degradasi mikrobiologis dan aktivitas enzim. Produksi ikan yang diolah 23-47\%; sisanya dijual dalam bentuk segar atau diekspor (Adawiyah, 2011). Pengolahan produk perikanan selama ini hanya mengandalkan pengolahan pada bagian daging ikan saja, oleh karena itu pengembangan produk olahan ikan ini akan diarahkan kepada konsep zero waste. Bahwa zero waste tersebut mencakup proses untuk memaksimalkan recycling, meminimalisasi limbah, mengefektifkan konsumsi dan memastikan suatu produk dapat didaur ulang sehingga limbah yang dihasilkan mendekati nilai nol (Zwia, 2004).

Program Kemitraan Masyarakat (PKM) ini adalah memberdayakan masyarakat untuk dapat melakukan diversifikasi pangan, sehingga di Kelurahan Pahandut Seberang sangat layak dilakukan penyuluhan dan pelatihan dalam pengolahan ikan berbasis zero waste menjadi produk dengan nilai jual yang tinggi. Ibu-ibu yang banyak 
menghabiskan waktu di rumah terkadang merasa bosan ataupun jenuh dan mereka mengharapkan adanya kesibukan yang bisa bermanfaat untuk kesejahteraan keluarganya. Tingginya minat masyarakat Kelurahan Pahandut Seberang, khususnya kaum ibu-ibu untuk maju merupakan alasan bagi tim pengabdian untuk memberikan pendampingan sekaligus pengetahuan tentang bagaimana cara mengolah ikan menjadi beberapa produk yang layak jual dengan menerapkan konsep zero waste. Data yang diperoleh dari hasil sebaran angket yang dilakukan menyatakan bahwa selama ini, mereka belum pernah mendapatkan pelatihan ataupun memperoleh pengetahuan tentang diversifikasi produk olahan ikan. Mereka hanya tahu memasak ikan untuk memenuhi konsumsi sehari-hari, seperti ikan goreng ataupun pais (pepes). Hasil angket juga memberikan informasi bahwa mitra sangat mengharapkan sekali adanya pelatihan pengolahan ikan. Berdasarkan berbagai permasalahan tersebut maka tujuan dari pelaksanaan PKM ini adalah sebagai berikut: memberikan pendampingan pemberdayaan terhadap ibu-ibu PKK Desa Pahandut Seberang melalui diversifikasi pengolahan hasil perikanan yang berbasis zero waste. Hal-hal yang perlu dikuasai oleh ibu-ibu PKK tersebut antara lain : 1) Pemilihan bahan baku produk olahan 2) Teknik penyusunan formulasi bahan-bahan olahan hasil perikanan, 3) Teknologi pengolahan berbasis zero waste, 4) Diversifikasi pengolahan hasil perikanan (kerupuk kulit ikan patin, nugget ikan patin, nugget ikan patin dan pakan buatan ikan budidaya). Kegiatan ini sangat perlu dilakukan untuk mengembangkan potensi sehingga dapat memberikan kontribusi positif bagi peningkatan ekonomi keluarganya. Kemudian kegiatan ini diharapkan memberikan multiplier effect positif terhadap komunitas ibu-ibu yang ada di Desa Pahandut Seberang secara keseluruhan sehingga dapat meningkatkan kesejahteraan keluarganya.

\section{METODE}

Metode yang digunakan dalam kegiatan ini adalah melalui pelatihan dan pendampingan. Dalam pelaksanaan kegiatan PKM ini, tahapan pelaksanaan kegiatan meliputi:

1. Tahapan Persiapan

Tahapan persiapan ini dimulai dengan observasi lokasi kegiatan PKM Kelurahan

Pahandut Seberang Kecamatan Pahandut Kota Palangka Raya untuk mendiskusikan strategi pelaksanaan PKM di wilayah tersebut. Selanjutnya tim berkoordinasi dengan LPPM-UPR dan instansi terkait koordinasi dan pengurusan izin pelaksanaan kegiatan serta meyepakati tanggal pelaksanaan. Pada tahap persiapan ini, tim melakukan penyiapan sarana prasarana pelaksanaan kegiatan seperti peralatan standar minimal yang dimiliki oleh mitra sasaran dalam pengembangan usaha.

2. Tahap Pelatihan Produksi.

Pelatihan produksi ini diberikan kepada kelompok mitra dimulai dari pemilihan bahan baku olahan dan pelatihan cara pengolahan berupa ikan segar. Kegiatan ini bersifat aktif dengan melibatkan peran mitra dalam proses pengolahan produksi. Materi dalam pelatihan ini diberikan kepada setiap peserta pelatihan untuk mempermudah peserta mencoba mengulang kembali secara mandiri sesuai dengan panduan materi (modul) yang diberikan. Sehingga kesiapan kelompok mitra menjadi kerupuk kulit, stick ikan dan nugget ikan patin dapat terealisasi sebagai upaya peningkatan perekonomian keluarga. Pelatihan akan dilakukan dengan metode praktek langsung dengan masyarakat tentang cara pelaksanaan pengolahan nugget ikan patin, kerupuk kulit, stik tulang ikan patin dan pembuatan pakan buatan dari jeroan ikan patin. 


\section{HASIL KARYA UTAMA DAN PEMBAHASAN}

\section{A. Tahapan tingkat pengetahuan awal mitra mengenai produk olahan ikan patin}

Penggalian informasi mengenai pengetahuan mitra tentang produk olahan ikan patin sangat diperlukan untuk mengetahui sejauh mana mitra mengenal atau memahami tentang produk maupun proses pengolahan ikan patin khususnya produk nugget ikan patin, kerupuk kulit ikan patin, stik dari tulang ikan patin dan pakan buatan ikan yang memanfaatkan jeroan ikan patin. Informasi yang diperoleh dapat digunakan sebagai indikator keberhasilan kegiatan dengan membandingkan antara wawasan mitra sebelum dan sesudah mengikuti kegiatan PKM. Penggalian informasi wawasan mitra dilakukan dengan membagikan kuisoner sebelum pelaksanaan kegiatan pelatihan. Kuisoner tersebut berisi pertanyaan seputar produk olahan ikan patin. Hasil penggalian pengetahuan mitra tentang produk olahan ikan patin dapat dilihat pada Tabel 1.

Tabel 2. Pengetahuan awal mitra tentang produk olahan ikan patin

\begin{tabular}{|l|c|c|c|}
\hline \multicolumn{1}{|c|}{ Jenis Olahan } & \multicolumn{3}{c|}{ Pengetahuan Mitra } \\
\hline & Tahu & Tidak Tahu & Jumlah \\
\hline Nugget ikan patin & $8(80 \%)$ & $2(20 \%)$ & 10 \\
\hline Kerupuk kulit ikan patin & $1(10 \%)$ & $9(90 \%)$ & 10 \\
\hline Stik tulang ikan patin & $1(10 \%)$ & $9(90 \%)$ & 10 \\
\hline Pakan buatan ikan dari jeroan ikan patin & $2(20 \%)$ & $8(80 \%)$ & 10 \\
\hline
\end{tabular}

Berdasarkan hasil dari Tabel 2, sebagian besar mitra sudah mengetahui tentang produk nugget ikan namun untuk produk kerupuk kulit, stik tulang dan pakan ikan yang memanfaatkan jeroan ikan patin lebih dari $80 \%$ mitra belum mengenal produk tersebut dan belum pernah melakukan pengolahan produk tersebut. Hal ini menunjukkan bahwa sebagian besar masyarakat di Kelurahan Pahandut Seberang belum mengenal produk-produk olahan dari limbah hasil perikanan dengan konsep zero waste (memanfaatkan keseluruhan bagian ikan patin). Hal ini tentunya akan menarik minat mitra untuk mengikuti keseluruhan rangkain kegiatan sehingga mereka mendapatkan pengetahuan dan meningkatkan keterampilan mengenai pembuatan produk olahan ikan patin.

\section{B. Tahapan Pelatihan Produksi Olahan Ikan Patin Berbasis Zero Waste \\ 1. Pembuatan Nugget Ikan Patin}

Salah satu makanan cepat saji yang menjadi alternatif masyarakat adalah nugget. Nugget yang terkenal di masyarakat adalah chicken nugget karena memang merupakan nugget pertama yang muncul dan dipasarkan di masyarakat. Seiring berjalannya waktu, nugget terus berkembang hingga ditemukan nugget ikan, yaitu nugget yang terbuat dari daging ikan.

Kegiatan ini dimulai dengan penjelasan singkat mengenai cara pembuatan produk olahan nugget ikan patin, kemudian dilanjutkan dengan praktek langsung pembuatan produk tersebut. Proses pengolahan nugget ikan patin seperti penjelasan berikut:

\section{1) Penyediaan Alat dan Bahan}

Alat yang digunakan dalam pembuatan nugget yaitu : pisau, gilingan, talenan, baskom, panci pengukus, stick bamboo, kompor, sendok, spatula, timbangan dan mixer. Sedangkan bahan yang digunakan dalam kegiatan ini adalah: daging ikan patin, garam, merica, mentega, tapioca, telur, gula pasir, bawang merah, bawang 
putih, bawang bombai, penyedap rasa, jahe, tepung terigu, royco, minyak goreng, soda kue, tepung terigu, tepung maizena dan air.

\section{2) Prosedur Kerja}

1) Fillet ikan dengan mengambil dan memisahkan daging dari kulit tulang ikan. Caranya adalah dengan meletakkan ikan diatas wadah, kemudian disayat memanjang dengan pisau pada ekor hingga kearah kepala, daging fillet diletakkan didalam wadah diberi es curai untuk mencegah peningkatan suhu dan menghambat pertumbuhan bakteri. 2) Giling fillet ikan dengan menggunakan grinder sehingga berbentuk pasta. Pada saat penggilingan harus diberikan garam secukupnya. Garam diberikan pada awal penggilingan berguna untuk meningkatkan kerekatan pasta ikan. jika dilakukan pada akhir penggilingan sifat kerekatan pasta akan menurun. 3) Masukkan pasta ikan ke dalam food processor untuk dilakukan pengadonan dengan penambahan tepung terigu dan bumbu seperti garam, merica, bawang putih dan bawang bombay yang sudah dihaluskan sebelumnya. Tambahkan tepung maizena sebagai bahan pengikat. Aduk campuran selama kurang lebih selama 20 menit agar adonan benar-benar homogen. 4) Cetak adonan menggunakan cetakan yang sesuai dengan standar misalnya berbentuk ikan dan lain- lainnya. Lakukan dengan cepat dan higienis. 5) Kukus nugget ikan lebih kurang 10-15 menit sampai adonan tersebut kenyal dan berbentuk keras dan terlihat mengembang. Hal ini disebabkan terjadinya proses koagulasi pada protein yang terdapat pada daging. Kemudian, dinginkan nugget ikan dengan cara diangin- anginkan. Setelah itu dilanjutkan dengan pencelupan kedalam tepung roti 6) Sebelum dicelupkan ke dalam tepung roti, nugget ikan terlebih dahulu dicelupkan ke dalam battering dan breading menggunakan terigu, air, garam dan tepung roti. 7) Simpanlah nugget ikan di dalam lemari pembeku agar daya awetnya bisa lebih panjang. Terlebih dahulu, nugget ikan dikemas menggunakan plastic yang permebilitasnya kecil untuk mempertahankan mutu nugget ikan pada saat penyimpanan. Alat pembekuan yang digunakan adalah Air Blast Freezer dengan suhu penyimpanan beku berkisar $-20^{\circ} \mathrm{C}$. 8) Sajikan nugget ikan dengan menggorengnya terlebih dahulu menggunakan minyak goreng panas (suhu $1700 \mathrm{C}$ ) selama 4-5 menit atau dimasak dengan menggunakan oven atau microwave.

Sedangkan dokumentasi pengolahan produk nugget ikan patin dapat dilihat pada Gambar 1 .
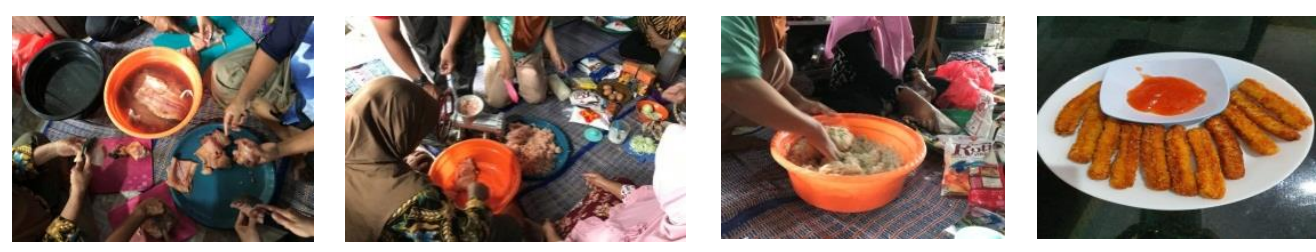

Gambar 1. Pengolahan Produk Nugget Ikan Patin

Ciri khas produk nugget ikan ini adalah memiliki tekstur yang elastis dan kenyal. Sifat elastis nugget ikan dipengaruhi oleh beberapa faktor, antara lain jenis ikan, tingkat kesegaran ikan, $\mathrm{pH}$ dan kadar air daging ikan, pencucian, umur ikan, suhu dan waktu pemanasan serta jenis dan konsentrasi zat tambahan. Mutu olahan nugget ikan yang baik adalah ketika tekstur nugget ikan yang dihasilkan adalah kenyal, rasa olahan nugget ikan tersebut gurih dan renyah karena adanya proses penambahan tepung roti yang memberikan kerenyahan produk, aromanya menunjukkan khas ikan serta berwarna kecoklatan setelah digoreng. 


\section{Pengolahan Kerupuk Kulit Ikan Patin}

Kegiatan selanjutnya adalah praktek pembuatan kerupuk kulit ikan patin. Kegiatan Praktek dimulai dengan menyiapkan alat dan bahan yang dibutuhkan dalam pembuatan kerupuk kulit ikan patin. Pelaksanaan praktek pembuatan ikan patin menjadi kerupuk kulit ikan patin dijalankan sesuai dengan langkah-langkah dalam pembuatan kerupuk kulit ikan patin yang telah dijelaskan di awal pertemuan. Praktek dijalankan oleh tim pengabdian dan dibantu juga oleh mitra yakni ibu-ibu PKK Kelurahan Pahandut Seberang yang langsung ikut mempraktekan pembuatan kerupuk kulit ikan patin. Para peserta sangat antusias dalam mengikuti kegiatan praktek tersebut, dan selalu bertanya apabila ada tahapan dan proses pengolahan yang kurang dimengerti. Proses pengolahan kerupuk kulit ikan patin seperti penjelasan berikut:

\section{1) Penyediaan Alat dan Bahan}

Alat yang digunakan dalam pembuatan kerupuk kulit yaitu : timbangan, gelas ukur atau takaran, gunting atau alat pemotong, yaitu untuk memotong bagian-bagian tertentu dari kulit ikan, bak plastic, baskom plastic, blender, alat penjemur , kompor, seperangkat a1 at penggoren, plastik sealer untuk pengemasan. Sedangkan bahanbahan yang diperlukan antara lain adalah: kulit ikan, bahan pengeras (firming agent), untuk mengeraskan kuIit ikan yang lembek, yaitu dengan cara direndam dalam air kapur sirih yang dibuat dengan melarutkan batu gamping secukupnya bumbu-bumbu, untuk menghasilkan cita rasa yang lezat, antara lain: garam 25 bawang putih 5 siung, ketumbar 2 sendok teh, asam $5 \mathrm{~g}$, dan air $250 \mathrm{~mL}$, minyak goreng dan bahan pengemas.

\section{2) Prosedur Kerja Kerupuk Kulit}

Cara pembuatan kerupuk kulit ikan terdiri dari beberapa tahap, antara lain:

\section{Tahap penyiapan bahan pengeras dan bahan baku}

a) Bahan pengeras pada prinsipnya dibuat dengan melarutkan kapur sirih atau batu gamping atau batu tohor dalam air secara terus menerus selama 7 hari hingga menjadi bubur kapur yang lembut.

b) Bahan baku berupa kulit ikan yang masih "kotor" yaitu yang masih bercampur dengan beberapa bagian ikan yang lain (sirip, ekor, isi perut, duri, ataupun kepala) harus dipisahkan dari bagian-bagian tersebut dan dipilih yang mempunyai kualitas baik. Setelah itu dibersihkan dengan air hingga benar-benar bersih dan ditiriskan. Bahan baku dari limbah kulit ikan yang sudah diawetkan sementara atau dikeringkan harus direndam beberapa saat hingga menjadi basah kemudian baru dapat diproses

c) Limbah kulit ikan yang telah bersih perlu disanitasi supaya terhindar dari cemaran mikroorganisme dengan menggunakan larutan perendam kaporit 0,25\% (b/v) selama \pm 1 menit. Selanjutnya dibersihkan beberapa kali dengan air hingga bau klor dari kaporit hilang, kemudian ditiriskan.

d) Dilakukan proses pengerasan dengan larutan kapur sirih selama 1-2 jam agar kerupuk ikan nantinya memiliki tekstur yang kaku, renyah, dan tidak mudak lembek. Untuk $10 \mathrm{~L}$ air perendam dibutuhkan 10 sendok makan air kapur sirih

e) Setelah proses pengerasan kulit ikan dicuci kembali dengan air hingga bau kapur yang menempel pada kulit ikan benar-henar hilang dan ditiriskan. Setelah ditiriskan kulit ikan yang telah keras tersebut dikeringkan. Kulit ikan yang telah kering ini siap untuk diolah. 


\section{Tahap pengolahan}

a) Kulit ikan yang telah kering dipotong dengan gunting untuk menyeragamkan bentuk dan ukurannya, sekaligus untuk memisahkan bagian-bagian lain dari ikan yang kemungkinan masih terikut, misalnya sirip, ekor, duri, dan lain-lain.

b) Selanjutnya direndam dalam larutan bumbu selama 5-10 menit, kemudian diangkat dan ditiriskan.

c) Kulit ikan yang sudah dibumbui dijemur hingga benar-benar kering. Pada waktu penjemuran sebaiknya dibolak-balik supaya keringnya benar-benar merata. Setelah kering dapat langsung digoreng atau disimpan dalam kantong plastik.

Dokumentasi pengolahan produk kerupuk kulit ikan patin dapat dilihat pada Gambar 2.
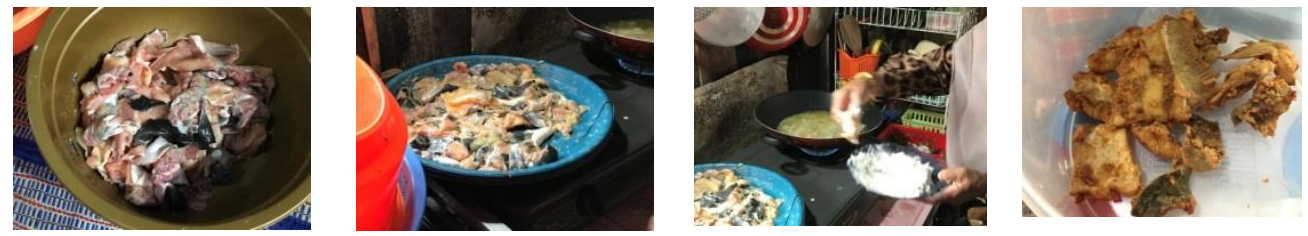

Gambar 2. Pengolahan Produk Kerupuk Kulit Ikan Patin

Kulit ikan dari hampir semua jenis ikan dapat dimanfaatkan dalam pembuatan kerupuk kulit ikan . Pengolahan kulit ikan menjadi kerupuk, memiliki prospek yang cukup bagus, mengingat bahan baku yang diperlukan sangat murah harganya, sementara kerupuk yang dihasilkan memiliki nilai ekonomi yang cukup tinggi, dan memiliki pasar luas baik di kalangan menengah maupun kalangan atas. Pengenalan Kulit kan Kualitas kulit ikan sangat tergantung pada jenis ikan dan cara pengolahannya. Pada umumnya limbah kulit ikan diperoleh dengan mudah dari sisasisa pengolahan daging ikan, seperti sisa pembuatan kerupuk ikan, bakso ikan, tepung ikan, abon ikan dan kecap ikan (Indraswari, 2003).

\section{Pembuatan Stik Tulang Ikan Patin}

Setelah praktek pembuatan kerupuk kulit ikan patin, kegiatan berikutnya adalah praktek pembuatan stik tulang ikan patin. Proses pembuatan stik tulang ikan patin seperti penjelasan berikut:

Proses pengolahan stik tulang ikan patin seperti penjelasan berikut:

\section{1) Penyediaan Alat dan Bahan}

Bahan yang digunakan adalah 350 gram terigu protein sedang, 70 gram tepung kanji, 1/2 sendok teh garam, 1 sendok teh baking powder, $1 / 2$ sendok teh kaldu ayam instan, 1/4 sendok teh merica bubuk, 70 gram margarin, 150 gram tulang ikan patin giling, 2 btr telur, kocok lepas, minyak untuk menggoreng secukupnya

\section{2) Prosedur Kerja}

(1) Bersihkan tulang ikan lalu rebus dalam panci bertekanan tinggi (presto) agar duri cepat lunak.

(2) Tulang yang telah lunak lalu digiling atau diblender.

(3) Campur tepung kanji, garam, baking powder, dan tepung terigu sambil di ayak.

(4) Tambahkan kaldu ayam instan, margarin, dan gilingan duri lele. Aduk dan uleni sampai semua bahan tercampur rata.

(5) Masukkan telur.

(6) Uleni sampai adonan menjadi kalis atau tidak lengket di tangan.

(7) Tipiskan atau gilas adonan dengan menggunakan penggiling mie atau rolling pan sampai ketipisan ukuran 1-2 mm

(8) Lalu potong sepanjang $10 \mathrm{~cm}$ atau sesuai selera. 
(9) Goreng sampai matang dan berwarna kekuningan. Lalu angkat dan tiriskan (10) Tunggu sampai stick dingin baru kemudian disimpan dalam toples / wadah yang tertutup rapat.

Dokumentasi pengolahan produk kerupuk kulit ikan patin dapat dilihat pada Gambar 3.
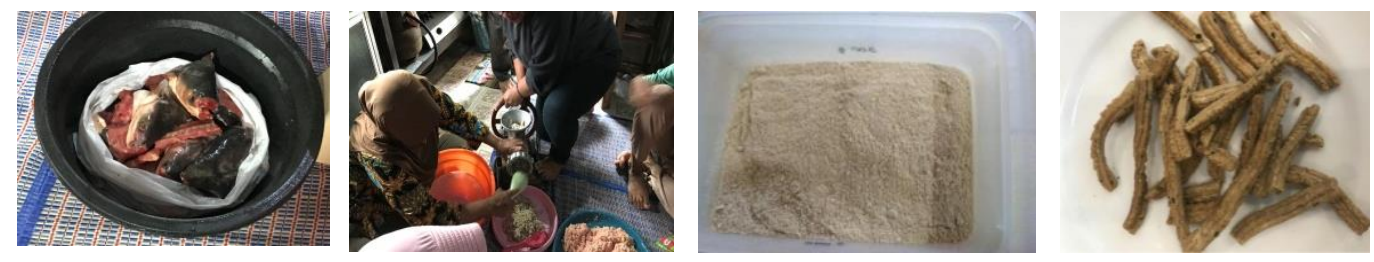

Gambar 3. Pengolahan Produk Stik Tulang Ikan Patin

Tulang ikan merupakan salah satu limbah dari industri perikanan yang belum dimanfaatkan dengan baik. Tulang ikan terdiri dari senyawa organik dan senyawa anorganik (mineral). Menurut Jung et al. (2005), tulang ikan hoki (Johnius belengerii) mengandung bahan organik sekitar $30,54 \%$ (bk) yang terdiri dari protein $28,04 \%$, lipid 1,94\% dan karbohidrat $0,56 \%$, sedangkan bahan mineral anorganiknya sekitar 69,46\% (bk) terutama terdiri dari 59,69\% kalsium (Ca) dan 35,81\% fosfor (P). Semua bagian dari ikan merupakan komponen organik yang seharusnya masih bisa dimanfaatkan sebagai sumber bahan pangan hewani. Penanganan limbah industri perikanan selama ini umumnya hanya dikubur dan diolah menjadi pakan ternak. Tulang ikan merupakan salah satu limbah hasil industri perikanan yang belum dimanfaatkan dengan baik. Salah satu hasil perairan yang kaya akan kalsium adalah ikan terutama bagian tulangnya. Kalsium dari tulang ikan memiliki kualitas cukup bagus serta mudah diperoleh. Salah satu pemanfaatan tulang ikan yaitu pengolahan menjadi tepung tulang. Pemanfaatan tepung tulang dapat dijadikan suplemen dan obat pencegah osteoporosis (Jiancong et al. 2010). Selain itu, tepung tulang dapat juga dimanfaatkan dalam pembuatan mie kering (Mulia 2004). Jenis ikan yang biasanya digunakan adalah tulang ikan patin, gabus, toman, lele, nila, dsb.

\section{Pembuatan Pakan Buatan dari Jeroan Ikan Patin}

Tahapan terakhir dari kegiatan praktek diversifikasi produk olahan ikan patin adalah pembuatan pakan buatan dari jeroan ikan patin. Proses pembuatan pakan buatandari jeroan ikan patin seperti penjelasan berikut:

\section{1) Penyediaan Alat dan Bahan}

Pembuatan pakan dilakukan dengan menyiapkan alat yang diperlukan, yakni : mesin pencetak pakan, sedangkan bahan yang diperlukan sebagai berikut: Ampas tahu (25\%), tepung ikan (5\%), tepung jagung (10\%), bungkil kedelai (10\%), dedak halus (15\%), bungkil kelapa (10\%), polard (15\%) dan bungkil kacang (10\%).

\section{2) Prosedur Kerja}

Bahan-bahan ditimbang sesuai dengan komposisi pelet yang akan dibuat, kemudian bahan diaduk atau mixer, perlu dilakukan penambahan cairan sesuai keinginan.Setelah dimixer selama 10 menit dan adukan benar benar rata kemudian adukan dicetak dengan mesin pencetak pelet. 
Dokumentasi pengolahan produk kerupuk kulit ikan patin dapat dilihat pada Gambar 4.
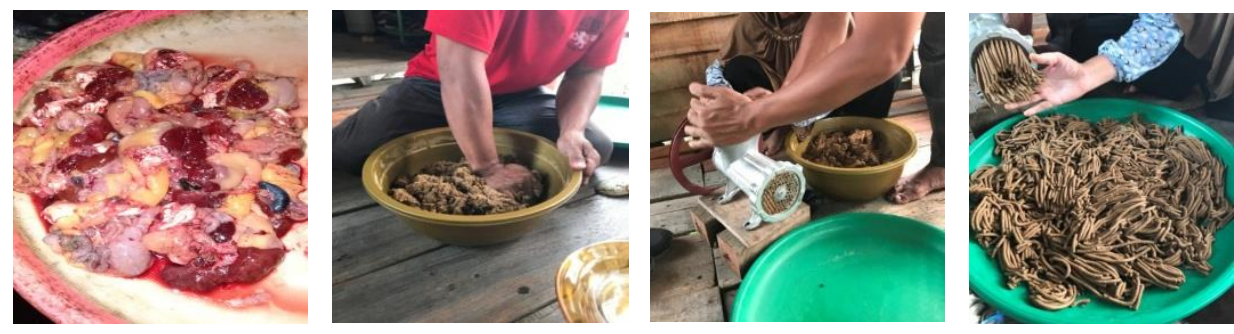

Gambar 4. Pengolahan Produk Pakan Buatan dari Jeroan Ikan Patin

Salah satu alternatif yang dilakukan untuk memaksimalkan pemanfaatan limbah hasil pengolahan ikan yang ada ialah melalui pemanfaatan limbah jeroan ikan patin, karena ketersediaannya yang melimpah dan belum dimanfaatkan secara maksimal, sehingga jika tidak dimanfaatkan dapat menyebabkan pencemaran pada lingkungan. Menurut Bhaskar et al. (2008) limbah industri perikanan misalnya jeroan memiliki kandungan protein dan lemak tak jenuh yang tinggi. Nurhayati $d k k, 2014$, menyebutkan bahwa pada jeroan ikan terdapat kandungan gizi yang cukup yakni protein 36-57\%; serat kasar 0,05-2,38\%; kadar air 24-63\%; kadar abu 5-17\%; kadar Ca $0,9-5 \%$, serta kadar P 1-1,9\%]. Hal ini menunjukkan bahwa jeroan ikan patin dapat dimanfaatkan lebih lanjut dan memiliki potensi sebagai bahan pakan sumber protein.

Pada tahap akhir kegiatan dilakukan penyerahan alat-alat produksi yang digunakan dalam pelaksanaan pengolahan produk ikan patin. Ketersediaan alat-alat produksi yang akan digunakan untuk memperlancar proses produksi dan usaha olahan ikan patin dan semua mitra yang terlibat menyatakan bahwa peralatan yang diberikan sudah memadai untuk proses produksi dan usaha produk olahan ikan patin. Dokumentasi penyerahan alat-alat produksi pengolahan produk ikan patin dapat dilihat pada Gambar5.
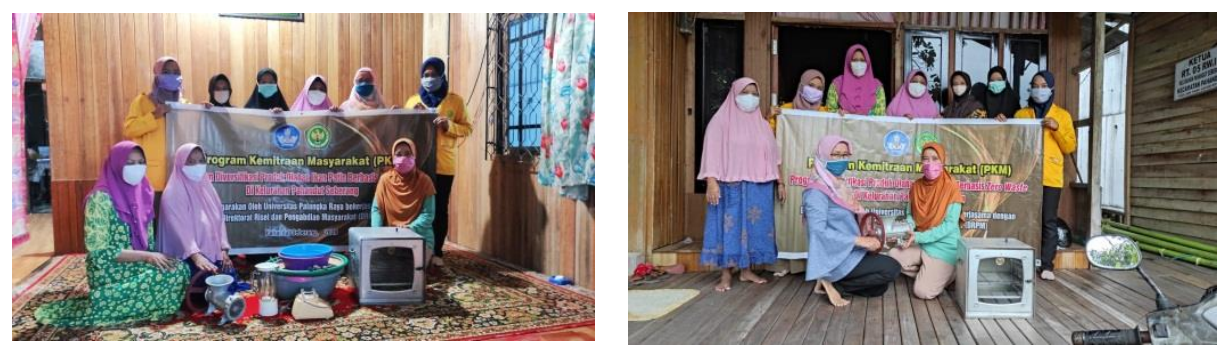

Gambar 5. Penyerahan Alat-alat Produksi Pengolahan Produk Ikan Patin

Pengolahan produk ikan patin menjadi nugget, kerupuk kulit, stik tulang ikan dan pakan buatan ikan di Kelurahan Pahandut Seberang sudah berhasil dilaksanakan dengan baik sesuai dengan rencana kegiatan. Kelompok masyarakat mitra sangat antusias mengikuti dan menerima pendampingan yang dilakukan oleh tim kegiatan pengabdian. Dalam kegiatan tersebut, ibu-ibu PKK telah terampil dalam pengolahan produk berbahan dasar ikan patin. Proses kerja pengolahan produk ikan patin oleh kelompok mitra dinilai sudah baik. Kemampuan kelompok mitra untuk mengikuti dan melaksanakan setiap langkah dan tahapan kerja sudah sesuai dengan prosedur yang ditetapkan. Aspek kebersihan dan ketertiban kerja kelompok mitra juga dinilai sangat baik. 


\section{Pendampingan}

Setelah pelatihan dilaksanakan, kelompok mitra didampingi sampai pada tingkat terampil. Target dari pendampingan yang dilakukan kepada kelompok mitra yakni mitra telah terampil mengolah produk kerupuk kulit, stick ikan, nugget ikan, pakan buatan bagi ikan budidaya dan berinovasi dengan produk olahan sehingga mampu memodifikasi olahan dengan rasa yang khas. Keberhasilan kegiatan ini tidak lepas dari peran serta dan partisipasi mitra. Oleh sebab itu, dalam rencana kegiatan, partisipasi mitra ditetapkan secara jelas dan menjadi tanggung jawab mitra untuk mencapai luaran masing-masing tahapan dan tujuan akhir kegiatan. Adapun uraian pelaksanaan kegiatan, luaran, dan bentuk partisipasi mitra dapat dilihat pada tabel 1.

Tabel 1. Uraian Rencana Kegiatan, Luaran, dan Partisipasi Masyarakat

\begin{tabular}{|c|c|c|c|c|}
\hline No & $\begin{array}{l}\text { Rencana } \\
\text { Kegiatan }\end{array}$ & $\begin{array}{c}\text { Metode } \\
\text { Pendekatan }\end{array}$ & Luaran & Partisipasi Mitra \\
\hline 1 & $\begin{array}{l}\text { Observasi } \\
\text { kegiatan }\end{array}$ & $\begin{array}{l}\text { Identifikasi } \\
\text { kebutuhan } \\
\text { kelompok mitra } \\
\text { dalam } \\
\text { pengembangan } \\
\text { usaha }\end{array}$ & $\begin{array}{l}\text { Data potensi } \\
\text { pengembangan } \\
\text { usaha mitra }\end{array}$ & $\begin{array}{lr}\text { Aktif } & \text { dalam } \\
\text { penyampaian } & \text { data } \\
\text { keberadaan } & \text { dan } \\
\text { potensi mitra } & \end{array}$ \\
\hline 2 & $\begin{array}{l}\text { Pengadaan dan } \\
\text { penggunaan } \\
\text { peralatan olahan } \\
\text { produk } \\
\text { kerupuk kulit, } \\
\text { nugget, nugget ikan } \\
\text { patin dan pakan } \\
\text { buatan dari jeroan } \\
\text { ikan patin }\end{array}$ & $\begin{array}{l}\text { Menyiapkan } \\
\text { peralatan } \\
\text { pelaksanaan usaha } \\
\text { sesuai dengan } \\
\text { standar minimum } \\
\text { pengembangan } \\
\text { usaha dan uji coba } \\
\text { penggunaan alat } \\
\text { oleh } \\
\text { mitra }\end{array}$ & $\begin{array}{l}\text { Alat pengolahan } \\
\text { standar minimum } \\
\text { dimiliki mitra dan } \\
\text { mitra terlatih } \\
\text { menggunakannya }\end{array}$ & $\begin{array}{l}\text { Mitra aktif berlatih } \\
\text { menggunakan } \\
\text { peralatan } \\
\text { untuk pengolahan } \\
\text { kerupuk kulit, } \\
\text { nugget, nugget ikan } \\
\text { patin dan pakan } \\
\text { buatan dari jeroan } \\
\text { ikan patin sebagai } \\
\text { produk unggulan } \\
\text { mitra }\end{array}$ \\
\hline 3 & $\begin{array}{l}\text { Pelatihan } \\
\text { produksi kerupuk } \\
\text { kulit, nugget, nugget } \\
\text { ikan patin dan pakan } \\
\text { buatan dari jeroan } \\
\text { ikan patin }\end{array}$ & $\begin{array}{l}\text { Praktek } \\
\text { simulasi }\end{array}$ & $\begin{array}{l}\text { Mahir mengolah } \\
\text { kerupuk kulit, } \\
\text { nugget, nugget } \\
\text { ikan patin dan } \\
\text { pakan buatan dari } \\
\text { jeroan ikan patin } \\
\text { yang memiliki ciri } \\
\text { khas produk } \\
\text { unggulan mitra }\end{array}$ & $\begin{array}{l}\text { Berpartisipasi aktif } \\
\text { dalam } \\
\text { pelatihan } \\
\text { pengolahan produk }\end{array}$ \\
\hline
\end{tabular}

\section{KESIMPULAN}

Beberapa hal yang dapat disimpulkan atas pelaksanaan kegiatan PKM adalah sebagai berikut : a) Para peserta kegiatan cukup antusias dan tertarik untuk mengembangkan usaha di bidang pengolahan ikan patin. b) Program PKM memberikan dampak positif baik bagi masyarakat Kelurahan Pahandut Seberang yakni terjadi peningkatan pengetahuan dan keterampilan masyarakat mengenai pemanfaatan ikan patin sebagai produk olahan pangan untuk memulai usaha di bidang pengolahan ikan patin. c) Potensi dan prospek usaha pengolahan ikan patin cukup baik untuk dikembangkan karena bahan baku yang cukup tersedia, memiliki tingkat keuntungan usaha yang cukup baik serta peluang pemasaran masih terbuka lebar. d) Tim PKM akan tetap memberikan pendampingan pemasaran dan pengurusan perijinan yangdiperlukan untuk menjalankan usaha pengolahan ikan patin. 


\section{UCAPAN TERIMA KASIH}

Ucapan terima kasih disampaikan kepada Direktorat Riset dan Pengabdian Masyarakat (DRPM) yang telah memberikan alokasi dana melalui Hibah Skim PKM Tahun 2020 untuk pelaksanaan kegiatan ini. Selain itu, ucapan terima kasih juga disampaikan kepada kelompok mitra ibu-ibu PKK Kelurahan Pahandut Seberang yang sangat membantu dalam terlaksananya kegiatan ini.

\section{DAFTAR PUSTAKA}

Adawyah, R. 2011. Pengolahan dan Pengawetan Ikan. Penerbit Bumi Aksara. Jakarta. 160 halaman.

Bhaskar, N dan Mahendrakar. N.S. 2008. Protein hydrolisate fromvisceral waste protein of catla (catla catla): optimazition of hydrolysis condition for acomercial neutral protease. Bioresource Technology 99: 4105-4111.

Indraswari, C.H., Rambak Kulit lkan. Yogyakarta: Penerbit Kanisius.

Jiancong, H., Shanggui, D., Chao, X., Guozhong, T., 2010. Preparation and biological efficacy of haddock bone calcium tablets. Chinese Journal of Oceanology and Limnology. Vol. 28(2): 371-378. DOI: 10.1007/s00343-0109019-0

Jung WK, Park PJ, Byun HG, Moon SH, Kim SK. (2005). Preparation of hoki (Johnius belengerii) bone oligophosphopeptide with a high affinity to calcium by carnivorous intestine crude proteinase. Food Chem 91: 333-340.

Mulia. 2004. Kajian potensi limbah tulang ikan patin (Pangasius sp) sebagai alternatif sumber kalsium dalam produk mi kering. Skripsi. Bogor: Fakultas Perikanan dan Ilmu Kelautan, IPB.

Nurhayati, Nelwida, dan Berlina. 2014. Perubahan Kandungan Protein dan Serat Kasar Kulit Nanas yang Difermentasi dengan Plain Yogurt. Jurnal Ilmiah ilmu-ilmu peternakan Vol XVII No. 1 Mei 2014.

Zwia. 2004. Zero Waste International Alliance, working towards without waste. [Internet]. [cited 26 Mei 2020]. Available from: http://zwia.org/standards/zw-definition/ 